\author{
ADAM F. BARAN
}

Instytut Studiów Politycznych PAN

\title{
HARCERSTWO NA EMIGRACJI WOBEC KOŃCA ODWILŻY PAŹDZIERNIKA'56 W KRAJOWYM ZHP
}

\section{Scouting in Exile at the End of the October ' 56 Thaw in the Polish Scouting and Guiding Association}

Since the establishment of courtesy relations between Warsaw and London in March 1957, through the exchange of correspondence between representatives of the authorities of the Polish Scouting and Guiding Association [ZHP] and the representatives of the ZHP Polish Scouting Association (abroad) [ZHPpgK], these relations were twofold. Due to the caution of the ZHPpgK authorities, the official relations never led to any formal cooperation (contract, resolution, etc.), and the unofficial relations are not well known yet. I have tried to describe the results of the research on this subject in a recently published book entitled $Z$ tymi co zostali... Harcerskie relacje Warszawa - Londyn (1945-1990) [with those who stayed... scouts' relations Warsaw - London (1945-1990)] [Warsaw 2016], yet this article presents the arrangements made between 1957 and 1959 and is complementary.

An important role in the period described was played by the then authorities of the global scouting, which tried to strengthen the 'power' of the arguments of the ZHPpgK authorities with their actions in 1957 and two years later. Invitation of the Polish delegation from ZHPpgK to two world scout jamborees was its actual confirmation and probably an attempt to repair old decisions concerning scouts operating among Poles in exile. Finally, in April 1959, in the newly adopted statute of the national ZHP (during the Second General Assembly of the ZHP), a record appeared that the organisation developed its activities in the territory of the Polish People's Republic and also 'cooperated with Polish youth abroad'. This record was thoroughly different from the one that was passed in December 1956 during the so-called National Congress of Scout Activists, stating that ' $\mathrm{ZHP}$ extends a fraternal hand to Polish scouts 
living outside the borders of our Homeland'. After two years of 'coexistence' under completely different conditions of two organisations of the same name, there was no mention either of the declared brotherhood or of the existence of an organisation that continued to be the rightful heir of the pre-war organisation on the ground of legalism. The changes that took place in the Polish ZHP at that time closed in a formal manner the next stage of the social thaw, which after October ' 56 also affected scouts in Poland. ZHP authorities operating outside the country (associated with the Polish government-in-exile), through their relentless attitude to events taking place in Poland, could have been satisfied that it was - as they often emphasised - a step towards the rebirth of ZHP, and in no case its reconstruction.

Keywords: emigration, scouting, London, October '56, ZHP, the Polish Scouting Association abroad.

Struktury harcerskie istniejące poza Polska po II wojnie światowej były jednymi $z$ najważniejszych ośrodków powojennej emigracji niepodległościowej, które działały wśród młodego pokolenia Polaków w sferze wychowania. W 1945 roku liczyły około 30 tysięcy członków, w tym 5 tysięcy dorosłych. Ich rola wzrosła wraz z likwidacja krajowych struktur Zwiazku Harcerstwa Polskiego (ZHP) przez komunistów po procesie podjętych działań i decyzji formalnych rozpoczętych w 1949 i przypieczętowanych w roku 1951 oraz powojennych represji, które dosięgły przedstawicieli wojennych Szarych Szeregów (konspiracyjnej struktury Organizacji Harcerzy ZHP), „Bądź Gotów” (konspiracyjnej struktury Organizacji Harcerek ZHP) czy całkowicie odrębnego od tych struktur Harcerstwa Polskiego o charakterze katolicko-narodowym ${ }^{1}$. W 1951 roku Naczelnictwu Zwiąku Harcerstwa

1 Zwiazek Harcerstwa Polskiego reaktywowano już 30 grudnia 1944 roku na terenach tak zwanej Polski Lubelskiej decyzją administracyjna resortu oświaty PKWN. Jednak sytuacja w strukturach konspiracyjnych organizacji harcerskich w kraju (Szare Szeregi, „Bądź Gotów” czy Harcerstwo Polskie) oraz więź ideowa i organizacyjna z rządem polskim w Londynie nie sprzyjały nowej władzy. Początkowo, mimo amnestii, większość instruktorów związanych z Szarymi Szeregami zachowała rezerwę i nie angażowała się organizacyjnie w krajowy ZHP. Harcerki z „Bądź Gotów” po zaprzestaniu jakiejkolwiek pracy konspiracyjnej z młodzieżą w 1945 roku także zdecydowały, aby nie wchodzić do władz organizacji powołanej $z$ nadania PKWN, ale nakierowały swoje działania na opiekę nad dziećmi i młodzieżą w różnych instytucjach, zachowując poufność kontaktów. Natomiast struktury Harcerstwa Polskiego nie zaprzestały działalności $z$ chwila nadejścia frontu i zakończenia II wojny światowej, uznając „nowy ZHP” jako komunistyczna przybudówkę, nadal działały w konspiracji (jednak już w grudniu 1945 roku nastąpiły pierwsze aresztowania w kierownictwie organizacji, a po rocznym śledztwie w lutym 1947 roku zapadły wyroki skazujace). Sytuację tę zmieniły częściowo: przyjazd do kraju Stanisława Mikołajczyka i powołanie Tymczasowego Rządu Jedności Narodowej oraz związane $z$ tym zmiany w składzie Naczelnictwa ZHP (w marcu 1946 r. funkcję wiceprzewodniczącego ZHP obją hm. Aleksander Kamiński jak przedstawiciel Szarych Szeregów). W rezultacie harcerska organizacja krajowa stała 
Polskiego poza granicami Kraju (ZHPpgK) podlegało bezpośrednio siedem zarządów okręgów w siedmiu krajach (Argentyna, Australia, Belgia, Francja, Kanada, USA i Wielka Brytania) oraz sześciu komendantów samodzielnych ośrodków harcerskich w sześciu dalszych krajach (Dania, Hiszpania, Holandia, RFN, Szwecja, Austria), i od tego czasu ZHPpgK był jedyną struktura, która zachowała ciągłość dziejów ZHP i jego prawnych podstaw ${ }^{2}$. Co ważne, władze organizacji $z$ siedziba w Londynie, zachowujacc statutowa apolityczność, od 1946 roku stawiały sobie za niezmienne zadanie służbę sprawie polskiej niepodległości, wiążąc swoja działalność z programową akcją całego obozu niepodległościowego. W sprawozdaniu przewodniczacego, dr. Michała Grażyńskiego z 3 marca 1951 roku czytamy m.in.:

Jeśli chodzi o stanowisko, jakie ZHP poza granicami Kraju zajmowała w sprawach narodowo-państwowych o znaczeniu zasadniczym, to stwierdzam, że zachował on w tym zakresie konsekwentną linię, zgodną z zasadniczą deklaracją ideową, uchwaloną na ogólnym zjeździe w Enghien. Stał, zatem nie tylko na gruncie swego pełnego współudziału w pracy i w walce niepodległościowej, ale także i na gruncie pełnej lojalności w stosunku do Zwierzchności Państwowej i praw Rzeczypospolitej. To dyktowało nam zarówno zachowanie pozytywnego stosunku do sprawy Skarbu Narodowego, jak i lojalnego i obywatelskiego stosunku do Prezydenta RP i Rządu Rzeczypospolitej na emigracji ${ }^{3}$.

W sierpniu 1957 roku, w Sutton Park (Anglia) odbyło się IX Jamboree, międzynarodowy zlot skautów $z$ całego świata. Mimo iż człon-

się z czasem realna siła (około 200-300 tys. członków), w której „czynniki demokratyczne” $\mathrm{z}$ komunistycznego nadania nie miały realnego wpływu na prace $\mathrm{w}$ drużynach, hufcach czy niektórych choragwiach ZHP. Ostatecznie, gdy władze przekonały się, że harcerstwa nie udało się przejać, nasiliły represje wobec instruktorów o „reakcyjnym rodowodzie”, zakwestionowały podstawowe idee skautingu (m.in. doprowadzajac do wyeliminowania ZHP z międzynarodowych struktur skautowych, co miało także zmarginalizować rolę działającego na emigracji ZHPpgK) i doprowadziły do likwidacji ZHP w Polsce. Zob. W. Hausner, M. Wierzbicki, Sto lat harcerstwa, Instytut Pamięci Narodowej, Warszawa 2015, s. 185-197. Por. A.F. Baran, $Z$ tymi co zostali... Harcerskie relacje Warszawa-Londyn (1945-1990), Instytut Studiów Politycznych PAN, Warszawa 2016, s. 28-40.

2 W. Hausner, M. Wierzbicki, Sto lat harcerstwa..., s. 203-207. Por. K. Sabbat, Organizacja i prace Zwiazku Harcerstwa Polskiego poza granicami Kraju, w: W. Kukla, M. Miszczuk, Co dalej? Instruktorzy harcerscy o Polsce, harcerstwie i młodzieży na łamach pism władz harcerskich na uchodźstwie (1940-1946), Wydawnictwo Tomiko, Warszawa 2016, s. 99; M. Wierzbicki, Zwiazek Harcerstwa Polskiego działajacy poza granicami kraju jako przedmiot badań naukowych, w: Emigracyjne miscellanea. Studia $z$ dziejów polskiej emigracji politycznej 1939-1990, red. S. Lukasiewicz, Instytut Pamięci Narodowej, Warszawa 2017 , s. 255-262.

3 Sprawozdanie Dr. M. Grażyńskiego, przewodniczacego Z.H.P. wygłoszone na Radzie Naczelnej Z.H.P. poza granicami Kraju w dniu 3-go marca 1951, w: W. Kukla, M. Miszczuk, Widziane $z$ Londynu. Stosunek emigracji londyńskiej do wyjazdów i kontaktów młodzieży $z$ emigracji z krajem 1949-1992, Wydawnictwo Tomiko, Warszawa 2018, s. 53-54. 
kostwo Polaków w strukturach skautowych zostało formalnie zakończone pod koniec lat czterdziestych XX wieku (na wniosek władz krajowego ZHP przejętego już przez komunistów), to do tego momentu kwestia sporna pozostawały relacje $z$ ZHPpgK. Ponieważ władze ZHPpgK nie zgodziły się nigdy $z$ uchwała władz skautowych, że skautingi uchodźcze, tolerowane $\mathrm{w}$ okresie wojennym, miały się połączyć ze skautingami krajów zamieszkania, w dotychczasowych relacjach z władzami skautowymi panował oczywisty „chłód”, choć na poziomie lokalnych struktur relacje jednostek ZHPpgK ze skautingiem były poprawne. Zaproszenie reprezentantów ZHPpgK na tak ważną imprezę, jaka było jubileuszowe Jamboree, uznano zatem za istotny zwrot w relacjach oraz - przypuszczalnie - możliwość pokazania swojej organizacyjnej „siły” także wobec struktur krajowego ZHP, w którym od grudnia 1956 roku podjęło walkę wewnętrzna o odrodzenie „prawdziwego harcerstwa" (jego idei, metod i form) w ramach organizacji, która powstała w wyniku kompromisu sił zorientowanych zachowawczo (wywodzących się ze Związku Młodzieży Polskiej czy Organizacji Harcerskiej Polski Ludowej), a dawnymi harcerkami i harcerzami reprezentowanymi we władzach przez przedwojennych i powojennych instruktorów ZHP oraz wywodzących się z kierownictwa konspiracyjnych „Szarych Szeregów” działających w czasie II wojny światowej.

Potwierdzenie tej tezy znajdujemy w nielicznych relacjach i dokumentach. Tak wspominał te wydarzenia po latach prezydent RP na Uchodźstwie, hm. Ryszard Kaczorowski ${ }^{4}$, w latach 1955-1967 naczelnik harcerzy ZHPpgK, a w latach 1967-1988 przewodniczacy ZHPpgK:

W roku 1957 odbywało się Jamboree światowe $z$ okazji 100. rocznicy urodzin Baden-Powella i 50 lat istnienia skautingu. Nasza wyprawa została zaproszona, a ponieważ to były trzy zloty: zlot instruktorski, zlot starszego harcerstwa i zlot harcerzy, braliśmy udział w tych trzech zlotach jako reprezentacja polska. Był wśród nas harcerz $z$ Warszawy. Nasza reprezentacja obejmowała harcerzy $z$ całego świata, poza Polska, i właśnie był jeden harcerz z Warszawy, którego obecność była symboliczna. Ale Polska była reprezentowana. Harcerstwo Polskie było reprezentowane na tym zlocie. Odwiedzali ten zlot różni ludzie, nawet władze polskie też posłały swego korespondenta, z którym nasz kontakt był bardzo nikły, ponieważ reprezentował zupełnie inne spojrzenie na swiat i rolę harcerstwa ${ }^{5}$.

4 Zob. A. Dobroński, Kaczorowski Ryszard, w: Harcerski Słownik Biograficzny, t. III, red. J. Wojtycza, Muzeum Harcerstwa, Marron Edition, Warszawa 2012, s. 98-100.

5 Nieformalnym reprezentantem krajowego ZHP na tym zlocie był hm. Jan Rossman, natomiast dziennikarzem krajowym, który wysyłał swoje korespondencje $z$ Jamboree do Polski, Kazimierz Koźniewski. Zob. A.F. Baran, $Z$ tymi co zostali..., s. 15-16. 


\section{A tak udział Polaków w skautowym Jamboree w 1957 roku wspo-} minał w ówcześnie wydanym, londyńskim „Na Tropie” prawdopodobnie były komendant reprezentacji polskiej (fragmenty):

Zjawienie się Polaków na Jamboree wywołało wrażenie piorunujące. Było zupełną niespodzianką dla niezliczonej rzeszy skautów i gości. Tysiące ludzi przekonać się mogło na własne oczy, że harcerstwo polskie istnieje. Mimo że było nas tak mało, dwoiliśmy się i troili, starając się być wszędzie: na dyskusjach, na ogniskach, na arenie i w obozach innych narodowości. [...] Można śmiało stwierdzić, że nasi chłopcy należeli do jednej z najpopularniejszych reprezentacji na Jamboree. Nasze obozy w Vogelenzang, na Rover Moot i Indabie roiły się od rana do wieczora od gości podziwiających nasza technikę obozownictwa i szukajacych okazji do wyrażenia swego uznania dla naszej pełnej godności postawy, jaka zachowaliśmy w tak trudnym dla nas okresie od czasu, gdy ZHP cofnięto uznanie.

Największa manifestacja tej sympatii dla nas była olbrzymia owacja, która zgotowała nam wielotysięczna publiczność w czasie defilady przed królowa brytyjską Elżbieta w dniu 3.VIII. br. Gdy drużyna polska ukazała się przed trybunami, gdy biało-czerwona flaga dumnie załopotała na wietrze, tysiace skautowych kapeluszy wyleciało w powietrze, tysiące dłoni bić poczęło huraganowe brawa, a $z$ piersi wielotysięcznego tłumu wyleciały gromkie okrzyki: „Niech żyje Polska!”

Ze ściśniętym gardłem, $z$ oczami przesłoniętymi mgłą rozczulenia, stałem opanowany wzruszeniem. Nagle na ramieniu swoim poczułem czyjaśs dłoń. Odwróciłem się. Otaczali mnie Węgrzy, Belgowie, Francuzi, Niemcy, Anglicy... Wszyscy ściskali dłonie, poklepywali po plecach... Jeden $z$ nich rzekł: „Nareszcie, nareszcie... Jak to dobrze znów widzieć Polaków wśród nas...”. W oczach miał łzy. Głos mu drżał. Był wzruszony nie mniej ode mnie.

I takich objawów przyjaźnie było więcej. [...] Musieliśmy odpowiadać na tysiące pytań. Ludzie chcieli się dowiedzieć jak najwięcej o Polsce, o harcerstwie polskim, o emigracji. [...]

Do wzrostu naszej popularności na Jamboree przyczynił się niewątpliwie fakt, że byliśmy jedyna grupa narodowościowa skautów spoza żelaznej kurtyny, występująca samodzielnie, pod własną flaga narodową. My Polacy mieliśmy własne obozy, na zewnattrz występowaliśmy jako grupa narodowa, pod polska flaga i $z$ napisem „Polska”. Ten fakt często doprowadzał do małych nieporozumień, bo wielu ludziom zdawało się, że przyjechaliśmy wprost z Polski ${ }^{6}$.

O ile w tym czasie władze ZHPpgK odnosiły na odcinku międzynarodowym istotne sukcesy, to w Polsce, w krajowym ZHP zaczęto

6 „Czapla”, Wrażenia z Jamboree, „Na Tropie” [Londyn] 1957, nr 9, s. 4-5. Por. zbiór (zbitka) artykułów z „Na Tropie” na temat udziału reprezentacji ZHPpgK w jubileuszowym Jamboree w Sutton Park (Anglia) 1-12 sierpnia 1957, Zwiazek Harcerstwa Polskiego poza granicami Kraju, Organizacja Harcerzy, kopia w zbiorach autora, http://www.zhpgkh.org/ index.php/download_file/view/411/142/Jamboree1957.pdf [dostęp: 8 listopada 2016], s. $9-11$. 
odnotowywać działania majace na celu neutralizację „skautów” i ich inicjatyw obliczonych m.in. na wykorzystanie możliwości ZHPpgK w kierunku wzmocnienia działań majacych na celu odrodzenie harcerstwa krajowego w możliwie tradycyjnym kształcie. Potwierdzaja to choćby zaczepne korespondencje prasowe Kazimierza Koźniewskiego z IX Jamboree w Sutton Park publikowane w prasie krajowej: „Sztandarze Młodych” (nr 196, 205, 240) i „Na przełaj” (nr 26, 27, 28 i 29), w których sporo dygresji - z punktu widzenia Koźniewskiego - o charakterze dyskusyjnym, ale też stawiających w niekorzystnym świetle nie tylko ZHPpgK, ale także organizację światowego skauting w ogóle ${ }^{7}$. A także nieudane próby pośredniczenia przez Koźniewskiego i Jerzego Żołnierkiewicza w nawiązaniu jakiejś formy współpracy na linii ZHP w kraju a ZHPpgK z września 1957 roku (wobec których emigracyjni gospodarze byli już odpowiednio przygotowani) ${ }^{8}$.

Warto w tym miejscu podkreślić, że niezależnie od opisanych wyżej okoliczności w okresie od kwietnia 1957 do stycznia 1958 roku władze ZHPpgK przesłały do Polski na 700 różnych adresów kilka tysięcy książek i kopii prasy o tematyce harcerskiej („Na Tropie” i „Znicz”), na łączną kwotę 1725 funtów brytyjskich wraz z kosztami wysyłki ${ }^{9}$.

Wobec zaistniałych wydarzeń niemniej ważna kwestią było ustalenie bieżącej polityki władz ZHPpgK w stosunku do działań mających na celu dezintegrację tej organizacji. Jak wiadomo, próby takie podejmowali przedstawiciele władz krajowego ZHP już w pierwszej połowie 1957 roku, ale deklaracje związane $z$ planami wydziału zagranicznego ZHP na rok 1958 i inne okoliczności (np. prowadzone przez polskie placówki MSZ PRL) musiały wywołać ostrą reakcję ${ }^{10}$. Tak też się sta-

7 Nie przytaczam wybranych treści tych korespondencji, gdyż ze względu na rolę, jaka pełnił wtedy K. Koźniewski (o czym piszę w jednym $z$ końcowych przypisów) materiały te wymagaja dodatkowej kwerendy źródłowej i odrębnej analizy. Były one jednak wnikliwie analizowane przez kierownictwo ZHPpgK. Zob. Instytut Polski i Muzeum Gen. Sikorskiego w Londynie [dalej: IPMS], sygn. KGA XX/ t. 1, Note: Concerning the participation of Polish Boy Scouts and Girl Guides in the 1957 Jamboree in Great Britain (brak datowania), k. 3-6.

8 M. Wierzbicki, Harcerz, żołnierz, obywatel. Zygmunt Lechosław Szadkowski (1912-1995), Instytut Pamięci Narodowej Oddział w Lublinie, Lublin 2016, s. 99. Por. A.F. Baran, $Z$ tymi co zostali..., s. 15 i 89-90.

9 IPMS, sygn. KGA XX/ t. 1, Polish Boy Scouts and Girl Guide Association, 31 January 1958, Notes: Concerningsending of books and periodical to Boy Scouts and Girl Guides in Poland, k. 1. Por. M. Wierzbicki, Harcerz, żolnierz, obywatel..., s. 98.

${ }^{10} \mathrm{~W}$ rozdziale siódmym swojej pracy pt. Stosunki zewnętrzne Zwiąku Adam Kiewicz pisał w 1989 roku m.in.: „Oferta w odniesieniu do harcerstwa emigracyjnego mogła być wyrazem zwrotu w stosunku władz państwowych do Polonii. Dawała wyraz więzi emocjonalnej łączacych harcerstwo krajowe $z$ emigracyjnym. W stosunku do emigracji z ostatniego okresu mogła sprzyjać podejmowaniu decyzji o powrocie do kraju. Wreszcie stanowiła ważny 
ło. W czasie zebrania Naczelnej Rady Harcerskiej (NRH) w Hastings (21-23 marca 1958 roku) podjęto uchwałę, w której NRH ZHPpgK wypowiedziała się przeciwko wyjazdom polskiej młodzieży $z$ emigracji na kolonie i obozy organizowane w Polsce oraz przeciwko oficjalnemu przyjmowaniu na emigracji zorganizowanych grup młodzieży przyjeżdżających na wycieczki z Polski. Swoją decyzję motywowano względami płynącymi $z$ niebezpieczeństwa infiltracji wpływów komunistycznych oraz ze względu na niebezpieczeństwo utraty charakteru niepodległościowego emigracji ${ }^{11}$. Co ważne, w ówczesnym dokumencie można było przeczytać także:

Rada Naczelna uważa, że wyjazdy poszczególnych osób z emigracji, a zwłaszcza instruktorek, instruktorów, st.[-arszych] harcerek i st.[-starszych] harcerzy w odwiedziny do Kraju sa szkodliwe, bo stanowia one bezpośrednie lub pośrednie uznanie reżymu komunistycznego w Kraju i zacieraja ideowe oblicze polskiego ruchu harcerskiego na obczyźnie ${ }^{12}$.

Według dokumentacji, do której dotarł Marian Miszczuk, w kwestii tej NRH ZHPpgK nie była jednomyślna. Za uchwała ta głosowały 52 osoby, przeciw 3, a 8 wstrzymało się od głosu ${ }^{13}$. I choć decyzja ta przez kilka kolejnych dekad była konsekwentnie podtrzymywana przez władze ZHPpgK, to już wtedy unaoczniła pewne zróżnicowanie. I o ile stosowano ją później konsekwentnie wobec emigracyjnej młodzieży harcerskiej, to niektóre instruktorski i niektórzy instruktorzy tej organizacji nie byli aż tak zasadniczy w tej kwestii ${ }^{14}$, co wywoływało ostre reakcje władz a nawet okresowe konflikty.

element uwiarygodnienia zmian dokonujacych się nie tylko $\mathrm{w}$ organizacji, ale również w kraju. Zapowiedź nawiązania kontaktów $z$ organizacjami skautowymi stanowiła nie tylko ukłon $\mathrm{w}$ ich stronę i wyjście naprzeciw zainteresowaniom przemianami w harcerstwie ze strony światowego skautingu. Leżała na linii większego otwarcia politycznego i chęci współdziałania naszego państwa $z$ krajami o odmiennych systemach społeczno-politycznych. Przemiany $\mathrm{w}$ harcerstwie były dyskontowane w działalności polskiej dyplomacji w krajach zachodnich". Zob. A. Kiewicz, Odrodzenie i odbudowa ZHP 1956-1959, [Na prawach rękopisu; do użytku wewnattrzorganizacyjnego], druk: Centralna Szkoła Instruktorów Zuchowych ZHP [Oleśnica], 1989, s. 82.

${ }^{11}$ M. Miszczuk, Ignacy Płonka i jego system zastępowy, Oficyna Wydawnicza „Impuls”, Kraków 2017, s. 85-86.

12 Ibidem, s. 86.

13 Ibidem.

14 „Pancewicz był także aktywny w harcerstwie. Po przybyciu [w 1947 roku do Anglii - przyp. A.F.B.] włączył się do pracy w powstajacej GK Harcerzy i przez kilkanaście lat prowadził referat wędrowników lub kierował wydziałem programowym. [...] Pancewiczowie mieszkali niedaleko Cambridge w Peterbourough. Syn i dwie córki wychowywały się w polskiej atmosferze, ale był czas - jak wspomina pani Janina - że "dzieci nie chciały przyznać się do polskości». To się całkowicie zmieniło także pod wpływem wizyt w Polsce. Pancewiczowie regularnie odwiedzali kraj. Powodowało to pewne komplikacje w pracy harcerskiej, 
Spośród znanych i udokumentowanych przypadków złamania uchwały NRH z pierwszego okresu jej obowiazywania dwa wydaja się charakterystyczne. Pierwszy dotyczył phm. Aleksandry Kulczyckiej, instruktorki Choragwi w Wielkiej Brytanii, która w 1959 roku podczas festiwalu artystycznego w Wiedniu podjęła na własną rękę nieoficjalna próbę nawiąania współpracy $z$ przebywajacymi na tej imprezie harcerkami z Polski. $Z$ ustaleń Marka Wierzbickiego wynika, że gdy o tej sprawie dowiedziała się naczelniczka Organizacji Harcerek ZHPpgK, ukarała ona swoja podwładna nagana ogłoszona w rozkazie. Ta jednak odwołała się od tej decyzji do władz organizacji, przy poparciu innych instruktorek choragwi i bliskich. Obrona swojego punktu widzenia na wiele się jednak nie zdała, gdyż władze ZHPpgK poparły decyzję naczelniczki i w rezultacie 10 marca 1960 roku phm. Kulczycka została usunięta $z$ organizacji i pozbawiona stopnia instruktorskiego. Nie zakończyło to jednak sprawy, a narastający konflikt wypłyną poza organizacyjne ramy. Ponieważ od wyroku w tej sprawie Naczelnego Sądu Harcerskiego (który orzekł brak podstaw do ukarania instruktorki i cofnięcie decyzji przełożonej) odwołało się Naczelnictwo ZHPpgK i doprowadziło do obalenia wyroku NSH w kolejnej instancji, zainteresowana zdecydowała się skorzystać $z$ usług sądu brytyjskiego. Ostatecznie nie doszło jednak do tej rozprawy, a kwestię sporna rozstrzygnięto polubownie na korzyść zainteresowanej ${ }^{15}$. Co ważne, druhna Kulczycka mimo zaistniałej sytuacji nie zrezygnowała $z$ późniejszej działalności harcerskiej. $Z$ czasem dosłużyła się stopnia harcmistrzyni, a w latach 1967-1997 była nawet członkinią Głównej Kwatery Harcerek ZHPpgK ${ }^{16}$.

Drugim przykładem, o znacznie większym kalibrze ze względu na osobę, był planowany, a następnie zrealizowany w 1959 roku wyjazd wakacyjny do Polski hm. RP Olgi Małkowskiej wraz z grupa dzieci. Ponieważ jego inicjatorka, niezwykle zasłużona instruktorka skautowa i harcerska, ostatnio była przewodniczaca Komitetu Naczelnego ZHP oraz członkini Naczelnictwa ZHPpgK, nie kryła swoich zamiarów, bo prawdopodobnie spodziewała się jakichś negatywnych reakcji. 16 marca 1959 roku, kilka miesięcy przed terminem zaplanowanego

bowiem wyjazdy do Polski były dla członków ZHP zakazane”. Za: M. Miszczuk, Bronisław Marian Pancewicz „Samotny Wilk” (1907-1983), „Harcerstwo” [Warszawa] 1991, nr 4-5, s. 52. Por. idem, Pancewicz Bronisław Marian, w: Harcerski Słownik Biograficzny, t. II, red. J. Wojtycza, Muzeum Harcerstwa, Warszawa 2008, s. 165-168.

${ }_{15}$ M. Wierzbicki, Harcerz, żołnierz, obywatel..., s. 134-136. Por. A.F. Baran, $Z$ tymi co zostali..., s. 94-95.

${ }^{16}$ A.F. Baran, $Z$ tymi co zostali..., s. 94. 
wyjazdu, napisał w tej sprawie list do hm. RP Olgi Małkowskiej dr Michał Grażyński, piastujący funkcję przewodniczącego ZHP jeszcze z przedwojennej nominacji, a w latach 1946-1951 były przewodniczący ZHPpgK. Sprawa była poważna, skoro sięgnięto w tej kwestii (władze ZHPpgK?) po taki organizacyjny autorytet. Grażyński w swoim liście nie krył krytycznej oceny tego przedsięwzięcia. Argumentował m.in., że wyjazd ten zostanie wykorzystany przez komunistyczny reżim w sposób propagandowy oraz że wywoła gorycz u tych, którzy wbrew optymistycznym opiniom działaczy komunistycznych stawiaja opór i walcza w kraju o pełnię zasad wychowawczych na odcinku harcerskim. Podkreślał także, że wiadomość o planowanym zamiarze Małkowskiej może mieć negatywny oddźwięk wśród starszej młodzieży na emigracji ${ }^{17}$.

Czy wobec takich argumentów Małkowska chociaż po części skorygowała swoje plany? Tego nie wiemy. Nie wiemy też, czy i jak Małkowska odpowiedziała na ten list. Musiała mieć jednak własne i zarazem odmienne motywacje, skoro latem 1959 roku w wieku 71 lat odwiedziła Polskę. Warto jednak podkreślić, że $z$ dotychczasowej literatury przedmiotu wiadomo jedynie, że w tym czasie nie była już związana z ZHPpgK tak silnie jak wcześniej, poświęcając się przede wszystkim pracy opiekuńczo-wychowawczej w sierocińcu dzieci polskich w Hawson Court (hrabstwo Devon). I gdy po powrocie $z$ wakacji do Wielkiej Brytanii jej podopieczni nie kryli zachwytu nad tak zorganizowanymi wakacjami, to negatywna ocena tej inicjatywy przez władze ZHPpgK (i być może inne ośrodki emigracyjne) prawdopodobnie zaciążyły na dalszych relacjach na gruncie organizacyjnym (choć nikt ich publicznie nie podnosił). Ostatecznie, w 1961 roku Małkowska wróciła do Polski i ostatnie lata swojego życia spędziła w Zakopanem, gdzie zmarła 15 stycznia 1979 roku urzeczywistniając swoja wolę (powiedziała kiedyś hm. Zofii Florczak, że dni które jej zostały chciała spędzić w Polsce i tu umrzeć) ${ }^{18}$.

Tymczasem, już w kwietniu 1959 roku w nowo uchwalonym statucie krajowego ZHP (podczas II Zjazdu Walnego ZHP) pojawił się zapis, że organizacja ta rozwija swoja działalność na obszarze Polskiej Rzeczypospolitej Ludowej oraz, że „współdziała z młodzieżą Polonii zagranicznej"19. Był to zapis biegunowo odmienny od tego, który został

17 Ibidem, s. 44.

18 Ibidem, s. 44-46.

19 „Wiadomości Urzędowe Związku Harcerstwa Polskiego” 1959 [Warszawa], nr 2, s. 3. Por. Wybór źródeł do dziejów ZHP, t. II: Walka, sowietyzacja, odwilż, kryzys i upadek (1944-1988), oprac. K. Marszałek, Oficyna Wydawnicza „Impuls”, Kraków 2014, s. 242. 
uchwalony w grudniu 1956 roku na tzw. Zjeździe Łódzkim, tj. że „ZHP wyciaga braterska dłoń do Polaków harcerzy żyjących poza granicami naszej Ojczyzny”" ${ }^{20}$. Po dwóch latach „koegzystencji” w zupełnie odmiennych warunkach dwóch organizacji o tej samej nazwie nie było już mowy ani o deklarowanym braterstwie, ani o fakcie istnienia w świecie organizacji, która nadal była pełnoprawnym spadkobierca przedwojennej organizacji na gruncie legalizmu. Zmiany, które dokonały się wtedy w krajowym ZHP, zamknęły w sposób formalny kolejny etap społecznej odwilży, która po Październiku '56 nastapiła także w krajowym harcerstwie. Władze ZHPpgK poprzez swoją nieugięta postawę w stawianych ocenach wydarzeń zachodzacych w Polsce mogły mieć satysfakcję, że był to - jak często podkreślano - etap w kierunku odrodzenia, a w żadnym wypadku odbudowa ZHP. Co ważne, ten punkt widzenia nie przekreślał i nie negował nigdy żadnych krajowych starań stojących w opozycji do systemu i podejmujących walkę o przywrócenie do życia tradycyjnych idei oraz form i metod harcerskich rożnymi sposobami. Potwierdzenie tego, choć w przewrotnej formie, znajdziemy m.in. we fragmencie uchwały pt. „Wytyczne do programu ZHP” krajowego II Zjazdu Walnego ZHP z kwietnia 1959 roku:

Październik przyspieszył te procesy, przerwał tamy ograniczajace inicjację. Nie wszystkie wśród zalewu projektów i rezolucji były słuszne, nie wszystkie czyste, nie wszystkie rozsądne. Nie tylko wychowawcy, którym leżały na sercu sprawy młodego pokolenia, i nie tylko postępowe siły społeczne interesowały się przeobrażającym się ruchem harcerskim. Wiązała z nim swe nadzieje także reakcja polityczna w kraju i za granica. Rachuby te nie spelnily się, ale wywierały swój wpływ na sprawy wewnątrzzwiązkowe [wyróżnienie - A.F.B.]. Zwyciężył pogląd, że należy szybko uwzględnić słuszne postulaty i zdecydowanie odrzucić tendencje zmierzające do reaktywowania - pod pretekstem "odnowy” - idei i metod, treści i form pracy nie nadażających za rozwojem życia społecznego. [...] Walka o program miała w tych warunkach charakter polityczny. Została ona w zasadzie zakończona zwycięsko. Decydujący wpływ na taki jej przebieg miała stabilizacja życia politycznego w kraju, przekraczająca nadzieje na „drugi etap” również w harcerstwie lub choćby na utrzymanie go $\mathrm{w}$ miejscu $-\mathrm{z}$ nowa ideologia $\mathrm{w}$ deklaracjach i zaprzeczająca jej, oparta na starym programie działania praktyką. Kto wiązal $z$ harcerstwem inne nadzieje, niż dobro młodzieży - musial odejść lub przynajmniej wycofać się na inne pozycje. Dziś już mało kto otwarcie podważa zasady ideowe naszego Związku, zawarte w Lódzkiej Deklaracji Ideowej [wyróżnienie - A.F.B.] ${ }^{21}$.

${ }^{20}$ Krajowy Zjazd Działaczy Harcerskich $w$ Łodzi [Uchwały, referaty, głosy w dyskusji], Państwowe Wydawnictwo „Iskry”, Warszawa 1957, s. 7. Por. Wybór źródeł do dziejów ZHP, t. II: Walka..., s. 127.

${ }^{21}$ Wybór źródeł do dziejów ZHP, t. II: Walka..., s. 135-137. 
W tym miejscu należy przypomnieć, że już w kwietnia 1958 roku, $\mathrm{w}$ wyniku umocnienia się oponentów hm. Aleksandra Kamińskiego i jego grupy, władze Głównej Kwatery Harcerstwa (krajowego ZHP) doprowadziły ostatecznie do rezygnacji „Kamyka” z funkcji przewodniczącego Naczelnej Rady Harcerskiej ${ }^{22}$. Był to efekt procesu, który trwał już od kilku miesięcy ${ }^{23}$, a o końcu „naszego działania” Kamiński rozmawiał m.in. $z \mathrm{hm}$. Janem Rossmanem ${ }^{24}$ (formalnie doradca NRH) już w lutym 1958 roku. A tak o okolicznościach odejścia $z$ funkcji i zarazem $z$ krajowej organizacji, m.in. po dwóch latach intensywnej pracy kształceniowej w ramach ZHP, pisał w liście z 26 września 1959 roku hm. Rossman do hm. Kazimierza Sabbata w Londynie, ówczesnego komisarza zagranicznego ZHPpgK:

W stosunku do wszystkich ustępujących zastosowano tę samą taktykę starannego odcięcia od wszelkich kontaktów i nieujawniania naszego odejścia. Nie zostaliśmy zwolnieni - nawet ci, którzy o to prosili. Po prostu zniknęliśmy, jakby nas nie było. Natomiast ustał bardzo nacisk polityczny i programowy. Pozostawia się „dołom” dosyć dużo swobody. „Góra” konsoliduje się wyraźnie na bazie dawnych elementów ZMP. Sa koncepcje akcji centralnych, dużej reklamy itp. Sypią się ordery, darmowe wycieczki zagraniczne, pieniądze, przywileje $^{25}$.

Warto jednak podkreślić, że odejście $z$ funkcji związanych $z$ władzami krajowej organizacji harcerskiej instruktorów, których głównym reprezentantem był Kamiński nie było jednoznaczne $z$ całkowita rezygnacją walki o kształt harcerstwa w tym czasie. Do czasu, kiedy to jeszcze było możliwe ${ }^{26}$, swoje oddziaływanie nakierowywano

${ }^{22}$ Ostatecznie, ponad rok później hm. A. Kamiński nie wziął udziału w II Zjeździe Walnym ZHP, który okazał się zaprzeczeniem wszystkich starań, które podjęto od końca 1956 roku w celu odrodzenia pracy harcerskiej w Polsce. Co ważne, od kwietnia 1958 roku były już przewodniczący Naczelnej Rady Harcerskiej nadal był objęty obserwacją operacyjna - w kwietniu 1959 roku donosił na „Kamyka” m.in. agent Służby Bezpieczeństwa TW „Wacław” (Andrzej Mazur). Zob. M. Goss, P. Spodenkiewicz, Bohater, konfident, prowokator, „Wieź” 2006, nr 2, s. 75. Por. A. Friszke, Związek Harcerstwa Polskiego 1956-1963. Społeczna organizacja wychowawcza $w$ systemie politycznym PRL, Instytut Studiów Politycznych PAN, Wydawnictwo Krytyki Politycznej, Warszawa 2016, s. 129.

${ }^{23}$ A. Friszke, Związek Harcerstwa Polskiego 1956-1963..., s. 69-72.

${ }^{24}$ Zob. M. Miszczuk, Rossman Jan, w: Harcerski Słownik Biograficzny, t. II , s. 179-183. Por. idem, Jan Rossman pseudonim „Wacek”, Wydawnictwo Tomiko, Warszawa 2009.

${ }_{25}$ M. Miszczuk, Jan Rossman pseudonim „Wacek”..., s. 179.

26 „Wiatr odnowy nie wiał długo. Ludzie o AK-owskiej przeszłości i niepodległościowych sympatiach nie awansowali; przeciwnie, pozbywano się ich przy byle okazji. W pierwszym rzędzie rozprawiono się $z$ komenda choragwi warszawskiej, $z$ Janem Rossmanem, Hanna Zawadzka, siostra legendarnego "Zośki" i Mirowskim. Komendantem hufca otwockiego został w 1958 roku oficer bezpieczeństwa, co dla Adama Strzembosza było ostatecznym sygnałem do wystapienia $z$ harcerstwa. Wystapiła cała jego drużyna. Hufiec przestał istnieć", 
na „doły”, stawiając jednocześnie na kształcenie nowego pokolenia instruktorów jako sprawę pierwszoplanową ${ }^{27}$. Ta aktywność była tolerowana jednak do czasu zaostrzenia kursu w państwie i w organizacji, i co najmniej od wiosny 1958 roku analizowana była także przez Służbę Bezpieczeństwa. Potwierdzaja to choćby agenturalne doniesienia tajnych współpracowników, które przywołał w swojej ostatniej książce Andrzej Friszke. Wynika $z$ nich m.in., że jesienią 1958 roku zauważono aktywność hm. Rossmana i bliskich mu osób. Negatywnie oceniano sytuację w Choragwi Warszawskiej ZHP, gdzie zespół partyjny miał praktycznie nie istnieć i $z$ tego powodu nie miał wpływu na podejmowane posunięcia programowe władz tej jednostki. Według doniesienia TW „K” (o nieustalonych personaliach), do stołecznych hufców mieli też zgłaszać się „reakcyjni instruktorzy” (m.in. hm. Stefan Mirowski ${ }^{28}$, $\mathrm{hm}$. Stanisław Broniewski ${ }^{29}$ ), a ówczesną aktywność innych, po rezygnacji $z$ funkcji w GKH i choragwi warszawskiej, oceniano jako „zorganizowaną ofensywę", aby mieć bezpośredni kontakt $z$ młodzieżą ${ }^{30}$.

W 1958 roku w krajowym ZHP zaostrzono też kurs wobec instruktorów, którzy nie kryli swojego przywiązania do Kościoła oraz tych jednostek, które naruszały zasady świeckości organizacji. Bohdan Cywiński, który jako student polonistyki na Uniwersytecie Warszawskim tuż po Październiku '56 dołączył najpierw do kręgu starszoharcerskiego przy Politechnice Warszawskiej (obejmującego ludzi z kręgów katolickich i gdzie żywe były tradycje szaroszeregowe), a po obozie

za: W. Borek, A. Urbański, Strzembosz - portret rodzinny, Wydawnictwo Baran i Suszczyński, Kraków 1995, s. 150. Por. T. Strzembosz, W stronę zachodzącego słońca. Życiorysy wpisane w polska historie, Oficyna Wydawnicza „Rytm”, Warszawa 2003, s. 24-25; A. Strzembosz, Między prawem i sprawiedliwościa, rozmawiał S. Zakroczymski, Biblioteka „Więzi”, t. 334, Warszawa 2017, s. 41.

${ }^{27} \mathrm{Z}$ notatek hm. Jana Rossmana obejmujących lata 1957-1958, do których dotarł Marian Miszczuk, wynika że 1 września 1957 roku w choragwi warszawskiej w 400 drużynach harcerskich udało się zorganizować ok. 10000 młodzieży, a przeszkolona starszyzna liczyła 190 harcmistrzów, podharcmistrzów i drużynowych po próbie. Odnotowano też, że w czasie akcji letniej rozpoczęto próby 200 przewodników i 50 podharcmistrzów, a wydział kształcenia choragwi przewidywał, że w roku szkolnym 1957/1958 trzeba wykształcić 330 przewodników i 100 podharcmistrzów. Zob. M. Miszczuk, Jan Rossman pseudonim „Wacek”..., s. 177. Natomiast w oficjalnym opracowaniu przygotowanym i przedstawionym w styczniu 1959 roku, podczas posiedzenia Sekretariatu KC PZPR, przez kierownictwo Głównej Kwatery Harcerstwa odnotowana m.in., że w obozach letnich w 1958 roku uczestniczyło 80 tysięcy młodszych i 7 tysięcy starszych harcerzy, a Centralną Akcją Szkoleniową objęto 1500 instruktorów. Zob. A. Friszke, Zwiazek Harcerstwa Polskiego 1956-1963..., s. 83-84.

${ }^{28}$ Zob. K. Kołodziejczyk, Mirowski Stefan, w: Harcerski Słownik Biograficzny, t. I, red. J. Wojtycza, Muzeum Harcerstwa, Warszawa 2006, s. 145-148.

${ }^{29}$ Zob. K. Wojtycza, Broniewski Stanisław, w: Harcerski Słownik Biograficzny, t. I, s. $22-26$.

${ }^{30}$ A. Friszke, Zwiazek Harcerstwa Polskiego 1956-1963..., s. 77-78. 
instruktorskim w 1957 roku założył własną drużynę na warszawskiej Ochocie, odczuł to osobiście. Jednak zanim jesienią 1958 roku stracił możliwość prowadzania pracy instruktorskiej, zorganizował dla swoich harcerzy wyjazd na obóz letni, zimowisko i kolejny obóz, w międzyczasie rozpoczynajac także drugi fakultet - studia $z$ filozofii chrześcijańskiej na $\mathrm{KUL}^{31} . Z$ perspektywy czasu wspominał:

Nie podjąłbym się oceniać tego, co działo się w harcerstwie już po moim odejściu jesienią $1958 \mathrm{r}$. Cały czas utrzymywałem bliższy lub dalszy kontakt $z$ kolegami, tyle że również i oni wypadli. Zależało to od konkretnego drużynowego, czy hufcowego. Istniały drużyny znakomite, które robiły to, co wcześniej myśmy w kręgu starszoharcerskim przy Politechnice, tylko inteligentniej, dzięki czemu ich drużynowi nie wpakowali się tak jak my. Były takie, które robiły połowę, a połowy nie robiły. I w końcu - nie robiące nic. Źle zadziałał pewien czynnik, niemajacy związku z ideologia. Funkcje instruktorskie przestało się pełnić społecznie. Chociaż chodziło o grosze, to drużynowymi zostawali ludzie, którym zależało na dodatku do pensji nauczycielskiej ${ }^{32}$.

A tak po latach, ze zbliżonej optyki, ocenił ten okres Tomasz Strzembosz, zaangażowany już od jesieni 1956 roku w odrodzenie harcerstwa w Polsce (poprzez zwiąki ze środowiskiem szaroszeregowym), potem także warszawski drużynowy, który na przełomie 1957 i 1958 roku ukończył kurs instruktorski dla przewodników w Zawoi pod Babią Górą:

Po okresie „liberalnym”, gdy stale zaostrzano „walkę o harcerstwo”, wybitni instruktorzy w wielu wypadkach odchodzili $z$ funkcji w choragwiach i hufcach, obejmując drużyny i w ten sposób, mniej widoczni, kontynuowali swoja służbę w myśl idei przez siebie wyznawanych. Było to charakterystyczne m.in. dla Krakowa i Poznania, dzięki czemu pałeczka podana w końcu 1956 r. kolejnemu pokoleniu polskiej młodzieży została przekazana, bardziej punktowo, dalszym pokoleniom, które nie traciły rozumienia, czym jest „prawdziwe harcerstwo”, harcerstwo „przedwojenne” - jak nieraz mawiano ${ }^{33}$.

31 „Harcerstwo, do którego trafiłem, nawiazywało do baden-powellowskiego skautingu, do polskiego harcerstwa sprzed wojny, skąd czerpało wszystkie sprawności i postulaty puszczaństwa. To puszczaństwo jakoś tak dziwnie pachniało partyzantką... Uczyliśmy się, jak rozpalić ogień $z$ niczego, przy użyciu samej woli, śpiewaliśmy piosenki partyzanckie $z$ lasu, w gawędach przy ognisku ciagle pojawiały się rozmaite postacie $z$ Szarych Szeregów... W sposób bardzo emocjonalny, czasami może przesadnie manifestacyjny, przeżywaliśmy swoją tożsamość, tradycję szaroszeregowa. Nie wiem, czy wszystkie drużyny, czy tylko niektóre, cechowały się mniej lub bardziej wyraźnym antykomunizmem. Dominowało przekonanie o konieczności wychowywania młodych, bo prędzej czy później zdarzy się coś, w czym będa musieli wziąc udział”. (z relacji Bohdana Cywińskiego), za: J. Błażejowska, Harcerska droga do niepodległości. Od „Czarnej Jedynki” do Komitetu Obrony Robotników. [Nieznana historii KOR-u i KSS „KOR”], Wydawnictwo „Arcana”, Kraków 2016, s. 63.

32 Ibidem, s. 65.

33 T. Strzembosz, W stronę zachodzacego słońca..., s. 26. Por. A. Janowski, Harcerstwo wpisane $w$ życiorys, Niezależne Wydawnictwo Harcerskie, Warszawa 2015, s. 254. 
Oficjalne wieści dotyczące zmian zachodzacych w krajowym ZHP docierały do Londynu błyskawicznie. Nawet ich pobieżna analiza wystarczyła, aby stosunkowo szybko dokonać oceny i wyciagnąc wnioski, które znajdowały potwierdzenie $\mathrm{w}$ innych źródłach niż prasa krajowa. A te $z$ poziomu władz ZHPpgK nie były już optymistyczne. Przewodniczacy ZHPpgK hm. Zygmunt Szadkowski ${ }^{34} \mathrm{z}$ żalem stwierdzał, że uchwały zjazdu, który miał miejsce w kwietniu 1959 roku w Warszawie, jego przebieg oraz sam okres przygotowań potwierdził „nasze obawy”. Zwracał uwagę na fakt, że dwuletnia zwłoka w organizacji zjazdu krajowego ZHP „została wykorzystana przez czynniki partyjne” na niekorzyść pierwotnych uchwał z grudnia 1956 roku. Przytaczał różne przykłady, ale także fragment wystapienia naczelniczki harcerstwa, hm. Zofii Zakrzewskiego $z$ nie tak dawno odbytego zjazdu PZPR, w którym podkreślała ona, że mimo iż harcerstwo było i jest wystawione na ataki kleru i reakcji, to aktualnie w zakresie wychowania młodego pokolenia będzie realizowało linię partii. Podkreślał, że korespondowało to nie tylko $z$ treścia podjętych uchwał i dokumentów, ale także $z$ lista przybyłych na zjazd oficjeli oraz okolicznościowym wystapieniem Władysława Gomułki, który powiedział m.in., że przewodnia myśla harcerstwa powinno być teraz „zdobywanie młodzieży dla socjalizmu". Zwracał też uwagę, że miażdżąca większość delegatów poparła ideowe przewodnictwo partii (tylko siedmiu było przeciw, a siedmiu wstrzymało się od głosu). Polemizował $z$ tezami zawartymi w artykule Kazimierza Koźniewskiego w „Polityce”, podkreślając, że to, co polska młodzież ma w sercach i duszach, nie moga przekreślić żadne uchwały, i stwierdził, że „w Polsce żywy jest prawdziwy ruch harcerski” ${ }^{35}$. Kończąc swoja analizę przewodniczący ZHPpgK pisał:

Kończac tych kilka uwag na temat sytuacji harcerstwa w Kraju muszę stwierdzić, tak jak to uczyniłem w moim liście z 18-go stycznia 1957 roku, że nie ma harcerstwa bez realizowania służby Bogu. Nie ma harcerskiego wychowania, pełnego człowieka, obywatela-Polaka, bez uwzględnienia w systemie wychowania młodzieży $i$ jej pracy nad soba, zasady wiary w nadprzyrodzony porządek świata i Boskie jego kierownictwo. Przyjęta w statucie zasada ideowego przewodnictwa partii komunistycznej, uzależnia wewnętrznie życie i pracę harcerstwa w Kraju od dyrektyw kontroli partii i to w dodatku od partii

${ }^{34}$ M. Wierzbicki, Harcerz, żołnierz, obywatel... Por. T. Szadkowska-Łakomy, A.Cz. Dobroński, Szadkowski Zygmunt Lechosław, w: Harcerski Słownik Biograficzny, t. IV, red. J. Wojtycza, Muzeum Harcerstwa, Muzeum Historii Polski, Wydawnictwo Marron, Warszawa 2016, s. 196-198.

${ }^{35}$ Z. Szadkowski, Po zjeździe w Warszawie, „Znicz” [Londyn] 1959, nr 2 [marzec kwiecień], s. 3-5. 
komunistycznej, wyznającej doktrynę materializmu dziejowego, oraz działającego totalnie w formie tak zwanej dyktatury proletariatu. Jest to zaprzeczeniem zasad demokracji, a wejściem na drogę monopartyjnego totalizmu.

Harcerstwo poza granicami Kraju jest nadal jedyną prawną i ideową kontynuacją Związku Harcerstwa Polskiego.

Wierzymy, że przyjdzie dzień, w którym w wolnej Ojczyźnie odbudowana zostanie prawdziwa organizacja harcerska, w ramach której będzie swobodnie mogła się rozwijać nasza ideologia oparta o służbę Bogu, Polsce i bliźnim ${ }^{36}$.

Poza wynikami II Zjazdu Walnego ZHP, po którym nastąpił w organizacji (przynajmniej na początku na poziomie władz) ostry zwrot w kierunku aprobowanym przez PZPR, latem 1959 roku w temacie ZHPpgK „przypomniał” o sobie Kazimierz Koźniewski. Jego publikacja w krajowym „Harcerstwie” miała charakter polemiczny i była „odpowiedzia” na tekst przewodniczacego ZHPpgK hm. Zygmunta Szadkowskiego, opublikowany w końcu lipca tego roku w londyńskim dzienniku „Orzeł Biały" (a pierwotnie w prasie harcerskiej). Osia tej publikacji, był wywód dotyczacy kwestii „służby Bogu” w harcerstwie, choć nie obyło się bez uszczypliwości personalnych (także wobec mieszkającego w Londynie hm. RP Henryka Glassa) oraz w stronę „polonijnej organizacji”, która miał kierować Szadkowski. Charakterystycznym elementem tej „wypowiedzi” było także uwypuklenie gwałtownych sporów ideowych w przedwojennym ZHP tuż przed wybuchem wojny, a także przypomnienie spornych kwestii dotyczacych harcerstwa na linii Warszawa - Londyn $z$ okresu okupacji. Z treści artykułu wynikało także, że choć obrona ówczesnego status quo krajowego ZHP była głównym celem Koźniewskiego, to celem nie mniej ważnym była kolejna próba dezintegracji środowiska („nie tylko na emigracji”), które poglądy ówczesnego przewodniczącego ZHPpgK podzielali ${ }^{37}$.

${ }^{36}$ Ibidem, s. 6.

37 K. Koźniewski, Mruczanka, „Harcerstwo” [Warszawa] 1959, nr 5-6, s. 95-96. Autor ten swoja krytyczną ocenę hm. RP Henryka Glassa „wzmocnił” rok później na łamach książki pt. Różowe cienie, którą według odautorskiego zapisu miał ukończyć jeszcze w 1958 roku. Zob. K. Koźniewski, Różowe cienie, Wydawnictwo Iskry, Warszawa 1960, s. 111 i 182. Dziś już wiemy, że te „wtręty” mogły mieć także odmienne podłoże, wynikające m.in. $z$ pozycji jaka zajmował Koźniewski, to jest wieloletniego tajnego współpracownika MBP (najstarszy zachowany donos nosi datę 22 marca 1947 roku), a od 1957 roku poufnego kontaktu i konsultanta SB, który działał także na odcinku emigracyjnym. Zob. J. Siedlecka, Kryptonim „Liryka”. Bezpieka wobec literatów, Prószyński i S-ka, Warszawa 2009, s. 165, 176 i 179 ; por. W. Frazik, Emisariusz Wolnej Polski. Biografia polityczna Wacława Felczaka (1916-1993), Wydawnictwo Attyka, Kraków 2013, s. 218-219. Kilka lat później hm. RP H. Glass „zrewanżował się” Koźniewskiemu, pisząc m.in: „Oprócz nacisku rządowo-partyjnego na ZHP, komuniści starali się też o wywołanie zamętu w umysłach młodzieży harcerskiej. Tej roboty podjął się niejaki Kazimierz Koźniewski, który kiedyś był drużynowym harcerskim, ale później zdradził ideologię harcerską i stał się bezbożnikiem i komunistą. Napisał on dwie książki: 
Swoistym epilogiem tej publicystycznej polemiki na linii Warszawa - Londyn było kolejne zaproszenie ze strony światowych władz skautowych i udział skromnej tym razem reprezentacji ZHPpgK (ze względów logistycznych i finansowych) w X Jamboree na Filipinach (17-26 sierpnia 1959 roku). A tak relacjonował udział w tym wydarzeniu jeden $z$ uczestników tej trzyosobowej wyprawy, hm. Szadkowski:

W sobotę, dnia 18 lipca odbyła się wielka defilada narodów. [...] W chwili, gdy przez megafony zapowiedziano, że oto zbliża się samotny harcerz polski z flaga polska - zerwała się burza oklasków. Było to najgorętsze powitanie zagranicznej delegacji. Tym harcerzem $z$ polskim sztandarem był Janusz Deszberg $z$ londyńskiego hufca harcerzy „Warszawa”. Był on w pełnym stroju harcerskim $z$ rogatywka i peleryna. Janusz, jak pisze miejscowa prasa, jest najpopularniejszym harcerzem Jamboree.

Przemarsz samotnego harcerza $z$ flaga polska przywołał na pamięć wydarzenie sprzed 39 lat, gdy w 1920 r. na pierwszym Jamboree w Anglii (hala Olimpii w Londynie) również samotny harcerz niósł flagę polską. Pozostali bowiem harcerze musieli pójść pod mury Warszawy, by bronić „zachodniej cywilizacji przed bolszewickim zalewem" ${ }^{38}$.

Od chwili nawiązania kurtuazyjnych stosunków na linii Warszawa - Londyn w marcu 1957 roku, poprzez wymianę korespondencji pomiędzy przedstawicielami władz krajowego ZHP, a przedstawicielem Naczelnictwa ZHPpgK, relacje te miały charakter dwojaki. Oficjalne, które ze względu na ostrożność władz ZHPpgK nie zostały nigdy doprowadzone do jakiegoś formalnego sposobu współpracy (umowa, uchwała itp.) oraz nieoficjalnie, o których wiemy jeszcze stosunkowo

"Różowe cienie" (Warszawa 1960) i "Ognie i ogniska" (Warszawa 1961), pełne fałszowania historii Harcerstwa oraz oszczerstw pod adresem przedwojennych twórców ZHP. Zadaniem Koźniewskiego w tych książkach było: a) zohydzenie wspaniałej przeszłości Harcerstwa i b) wysunięcie fałszywej tezy, że Harcerstwo nie miało żadnej ideologii(!) i że dopiero komunizm przyniósł młodzieży polskiej ideologię "prawdziwą i postępową"!!). Według wiadomości z Kraju Koźniewski cieszy się taką opinią, na jaką zasługuje...”. Za: C.S. Maresz [właśc. Henryk Glass], „Komunizm przeciwko harcerstwu”, maszynopis referatu, brak daty (prawdopodobnie 1966 rok), kopia ze zbiorów dr. hm. Leonidasa Kliszewicza (Nottingham), w zbiorach autora, s. 10. Artykuł tego autora, pod tym samym tytułem, ukazał się w styczniu 1967 roku na łamach londyńskiego „Orła Białego” (nr 30), a kilka miesięcy później jako kilkustronnicowa broszura wydana w Londynie nakładem Stowarzyszenia Polskich Kombatantów. Zob. W. Kukla, M. Miszczuk, Polish Scouting Publishing in the United States of America, the Unitet Kingdom, Canada and Australia (1913-2009). Outline of History and Bibliography / Harcerska działalność wydawnicza w Stanach Zjednoczonych Ameryki, Wielkiej Brytanii, Kanadzie i Australii (1913-2009). Zarys dziejów wraz z bibliografia, Wydawnictwo Tomiko, Warszawa 2009, s. 218. Por. A. Glass, Glass Henryk Stanisław, w: Harcerski Słownik Biograficzny, t. II, s. 82-89.

${ }^{38}$ Z. Szadkowski, Światowy zlot harcerzy na Filipinach z udziałem Polaków, „Orzeł Biały" [Londyn] 1959, nr 32, s. 2. 
niedużo. Dotychczasowe wyniki badań na ten temat starałem się ogłosić w wydanej ostatnio ksiażce pt. $Z$ tymi co zostali... Harcerskie relacje Warszawa - Londyn (1945-1990) [Warszawa 2016], jednakże publikacja ta ma charakter uzupełniający badania, które nadal sa prowadzone. I ponieważ na wiele pytań nie mam jeszcze odpowiedzi, to obok zamieszczonych powyżej ustaleń, chciałbym je uzupełnić o pewne spostrzeżenia i tropy.

1. Trudno nie odnieść wrażenia, na podstawie dotychczasowej literatury przedmiotu, że aktywność Kazimierza Koźniewskiego także po Październiku '56 była w jakiejś mierze nakierowana na sprawy harcerskie. W przypadku środowiska krajowego, nie miał on już najmniejszych szans na większe sukcesy operacyjne, gdyż był skompromitowany co najmniej od kilku lat, za sprawą tzw. Listu z 1953 roku (Do byłych instruktorów[-ek], działaczy[-czek] oraz członków byłego Zwiazku Harcerstwa Polskiego) ${ }^{39}$. Nie dziwi zatem jego „zainteresowanie" sprawami ZHPpgK i skautingu w tym czasie. Włączenie jego osoby w pierwotny skład wydziału zagranicznego Głównej Kwatery Harcerstwa krajowego ZHP stosunkowo szybko wyszło na jaw, podobnie jak „dziennikarska” aktywność podczas skautowego Jamboree w Wielkiej Brytanii w sierpniu 1957 roku nakierowana na reprezentantów ZHPpgK na tym międzynarodowym zlocie. Trudno się zatem dziwić, że już miesiąc później przy oficjalnej próbie rozmów $z$ władzami ZHPpgK, jako jeden $z$ dwóch reprezentantów krajowych władz ZHP, został potraktowany chłodno i odprawiony $z$ kwitkiem. Zaistnienie Koźniewskiego na tym odcinku mogło mieć jednak drugie dno, którym było także odwrócenie uwagi od innych agentów, którzy rozpracowywali w latach 1957-1960 kierownictwo ZHPpgK, a także ich krajowych sojuszników w szeregach odradzającego się ZHP w kraju. Z dotychczasowych badań wynika, że byli nimi TW „Riano” i TW „Henryk”" .

39 Zob. G. Motyka, R. Wnuk, T. Stryjek, A.F. Baran, Wojna po wojnie. Antysowieckie podziemie $w$ Europie Środkowo-Wschodniej $w$ latach 1944-1953, Muzeum II Wojny Światowej, Instytut Studiów Politycznych PAN, Wydawnictwo Naukowe Scholar, Gdańsk - Warszawa 2012, s. 320-322. Por. W. Hausner, M. Kapusta, M. Konieczna (współpraca), Epizody harcerskiej konspiracji niepodległościowej na ziemi krakowskiej 1944-1953, Wydawnictwo Avalon, Kraków 2014, s. 132-136.

40 Zob. Instytut Pamięci Narodowej [dalej: IPN], Oddziałowe Biuro Udostępniania i Archiwizacji Dokumentów w Krakowie, sygn. Kr, nr 47/23, August Zaleski i inni, t. 3 (dot. K. Sabbata, Notatka sporządzona na podstawie sprawy archiwalnej Nr 37169/b - Materiały za okres od 1957 do 1960 od agentów „Riano” i „Henryk” zestawił mjr C. Kozubski, st. oficer operacyjny Wydziału VIII D-I (akta odtworzeniowe $z$ mikrofilmu IPN BUiAD Warszawa, sygn.. 01277/576), k. 20-22. Por. K. Tarka, Wywiad PRL na tropie Kazimierza Sabbata, „Archiwum Emigracji. Studia - Szkice - Dokumenty” [Toruń] 2011, z. 1-2, s. 289-293; A.F. Baran, $Z$ tymi co zostali..., s. $145-147$. 
Co ważne, Marian Miszczuk w wydanej ostatnio pracy zbiorowej, w rozdziale na temat harcmistrzów Henryka i Marii Kapiszewskich ujawnił, że hm. Kapiszewski ${ }^{41}$ był inwigilowany także po 1956 roku. Jak napisał, była to osoba „niemal poza podejrzeniami”, najbliższy współpracownik hm. Stanisława Broniewskiego i przyjaciel rodziny Rossmanów, były wizytator „Pasieki” - konspiracyjnej Głównej Kwatery „Szarych Szeregów” . Powołując się na materiały IPN, dodał tė̇, że wspomniany agent TW „Henryk” miał nie tylko donosić na Kapiszewskiego, ale także na hm. Jana Rossmana oraz hm. Andrzeja Ferstena $^{42}$. Wszystko wskazuje na to, że był to ten sam agent, który działał w tym czasie także na odcinku emigracyjnego harcerstwa.

2. Nadal pozostaje otwarta kwestia identyfikacji osób, które kontaktowały się $z$ przedstawicielami kierownictwa ZHPpgK w sposób poufny. Dziś, za sprawą badań Mariana Miszczuka, wiemy na pewno, że osoba która bywała w Londynie od sierpnia 1957 roku stosunkowo często i cieszyła sie zaufaniem władz ZHPpgK był m.in. hm. J. Rossman ${ }^{43}$. Niemniej $z$ dokumentów do których dotarłem wynika, że na przykład podczas IX Jamboree w Sutton Park goszczono nie jednego, a dwóch krajowych instruktorów (w tym Rossmana), a $z$ innymi o tej postawie ideowej i zbieżnych poglądach władze ZHPpgK były w stałych kontaktach osobistych (odbywających się w Anglii lub na kontynencie) oraz korespondencji pocztowej, które sięgały już Października '56. Źródło to nie wymienia nazwisk, ale czytelnie podaje, że nie chodziło tu o osoby, które pojawiły się na Jamboree jako osoby prywatne przy okazji wizyty u krewnych w Anglii (będąc instruktorami krajowego ZHP) lub jako delegaci „komunistycznych władz harcerskich” (Koźniewski i Żołnierkiewicz) ${ }^{44}$. Jak widać sprawa ta jest niezwykle zawiła i trudna, ale próby jej rozwikłania moga przyczynić się nie tylko do ustalenia działan agentury w środowisku emigracji, ale przede wszystkim oddania należnego szacunku tym wszystkim, którzy narażając się na

${ }^{41}$ Zob. K. Jarzembowski, A. Winnicki, Kapiszewski Henryk, w: Harcerski Słownik Biograficzny, t. I, s. 89-91. Por. M. Miszczuk, Kapiszewska z Zakrzewskich Maria Janina, w: Harcerski Słownik Biograficzny, t. IV, s. 98-101.

42 Kapiszewscy. Saga o losach polskiej inteligencji, praca zbiorowa, Krakowska Akademia im. Andrzeja Frycza Modrzewskiego, Kraków 2017, s. 360.

43 W wyniku jego wieloletnich kontaktów w Londynie znalazł się m.in. pokaźny zbiór dokumentów dotyczących „Szarych Szeregów” (w zbiorach jego kuzynki Haliny Martin), które zostały opracowane i wydane w książce pt. Szare Szeregi. Związek Harcerstwa Polskiego w czasie II wojny światowej. Główna Kwatera Harcerzy „Pasieka”. Ocalałe dokumenty. Dokumenty ze zbiorów archiwalnych w Warszawie i Londynie skomentowane przez Jana Rossmana, pseud. „Wacek”, byłego członka „Pasieki” Szarych Szeregów, Londyn 1982.

44 IPMS, sygn. KGA XX / t. 1, Note: Concerning the participation of Polish Boy Scouts and Girl Guides in the 1957 Jamboree in Great Britain (brak datowania), k. 2. 
represje ze strony reżimu, podejmowali się tego niezwykle trudnego zadania na drodze do odrodzenie harcerstwa w Polsce.

3. Warto $\mathrm{w}$ tym miejscu także przypomnieć, iż ostatnimi dokonaniami hm. Aleksandra Kamińskiego o tematyce harcerskiej były prace biograficzne. Mam tu na myśli książkę (której współautorem był $\mathrm{hm}$. Antoni Wasilewski) o hm. Józefie Grzesiaku „Czarnym”, wybitnym instruktorze harcerskim, byłym komendancie Wileńskiej Choragwi Harcerzy ZHP (podczas okupacji w strukturach „Szarych Szeregów”), oficerze AK, aresztowanym przez NKWD w Wilnie i skazanym na dziesięć lat łagrów. Druga była książka, niestety niedokończona, o dr. Michale Grażyńskim ${ }^{46}$, byłym wojewodzie śląskim, przewodniczącym ZHP jeszcze $z$ przedwojennej nominacji oraz pierwszym przewodniczacym ZHPpgK. Nie wiemy, jakie były główne motywacje „Kamyka”, ale wybór bohaterów kolejnych książek spośród grona niewątpliwie niewygodnych dla komunistów był charakterystyczny. Co ważne, w przypadku „Czarnego” ksiażza ukazywała postać zaangażowaną w odrodzenie krajowego harcerstwa po Październiku '56 i niewatpliwie skrzywdzoną w ówczesnych okolicznościach przez przeciwników politycznych z kierownictwa krajowego $\mathrm{ZHP}^{47}$, a który jeszcze jako delegat II Zjazdu Walnego ZHP wystąpił $z$ krytyczna ocena sytuacji $w$ organizacji i w niesprzyjających okolicznościach m.in. wspominał o osiagnięciach przedwojennego ZHP, potrzebie nawiązywania kontaktów $z$ emigracyjnym harcerstwem i roli drużyny jako miejsca wychowania przyszłych instruktorów ${ }^{48}$. Natomiast ksiażka o Grażyńskim, gdyby powstała (autor ukończył zaledwie trzy rozdziały i doprowadził biografię do 1925

${ }^{45}$ Zob. J. Wojtycza, Grzesiak Józef Andrzej, w: Harcerski Słownik Biograficzny, t. I, s. $58-62$.

${ }^{46}$ Zob. K. Jarzembowski, P. Zarembski, Grażyński Michał Tadeusz, w: Harcerski Słownik Biograficzny, t. I, s. 47-52.

47 „Jego metody i poglądy na prace harcerską nie mieścily się w ramach jeszcze niezupełnie odnowionego ZHP, toteż napotykały na przeszkody w Główne Kwaterze, gdzie był traktowany nieufnie i niechętnie. Zrezygnował ze stanowiska jej członka, a w październiku 1958 r. został zwolniony ze stanowiska komendanta Choragwi Gdańskiej. W decyzji uzasadniającej zwolnienie podano, że jego linia ideowo-wychowawcza jest niezgodna $z$ linią ideowo-wychowawcza ZHP. [...] Czarny nie przestał interesować się harcerstwem do końca życia, korespondował z Trzynastakami żyjącymi w kraju i za granica”. Za: A. Wasilewski, Zarys dziejów Wileńskiej Choragwi Harcerzy. Czarna Trzynastka Wileńska [Harcerska Biblioteka Kresowa], Związek Harcerstwa Polskiego na Litwie, Związek Harcerstwa Rzeczypospolitej, Wilno - Warszawa 2008, s. 246. Por. A. Kamiński, A. Wasilewski, Józef Grzesiak „Czarny”, wstęp: S. Broniewski „Orsza”, Biblioteka Literacka i Historyczna, Biblioteczka „Bratniego Słowa" (drugi obieg), [Warszawa 1981], s. 73-76.

${ }^{48}$ J. Wojtycza, Grzesiak Józef..., s. 61. Por. Nasz Zjazd. II Zjazd Walny Zwiazku Harcerstwa Polskiego, Warszawa, 18-21 IV 1959 r. Referaty, dyskusja, uchwały, Wydawnictwo Harcerskie, Warszawa 1959, s. 169-173. 
roku), mogłaby ukazać nie tylko zawiłe dzieje międzywojennego ZHP, ale przede wszystkim obraz harcerstwa na emigracji po wybuchu II wojny światowej, tj. od momentu zawiązania na czas wojny Naczelnego Komitetu Wykonawczego ZHP z siedzibą w Paryżu (9 września 1939 roku), poprzez udział w powojennej budowie struktur ZHPpgK, aż do zrzeknięcia się przez Grażyńskiego funkcji przewodniczącego ZHP w listopadzie 1960 roku. Trudno jednak nie oprzeć się wrażeniu, że w tym drugim wypadku, przede wszystkim ze względu na stan zdrowia i wiek autor musiałby mieć zagwarantowana pomoc w poszukiwaniach źródłowych na Zachodzie. A ponieważ temat emigracyjny był szczególnie wrażliwy dla władz PRL, musiała to być osoba nie tylko o stuprocentowym zaufaniu Kamińskiego, której okresowa praca w Paryżu lub Londynie dawała takie możliwości, ale także sprawdzona przez osoby i ośrodki dysponujące wiedza źródłową $z$ lat 1939-1965.

4. Jest też sprawą znamienną, że o ile kilku czołowych instruktorów krajowych utrzymywało kontakty (bezpośrednie lub pośrednie) z kierownictwem ZHPpgK od chwili powstania tej struktury w 1946 roku, to hm. Stanisław Broniewski „Orsza”, były naczelnik Szarych Szeregów, praktycznie przez cały okres PRL zachowywał w tej kwestii wstrzemięźliwość. Od czasu powrotu do kraju, zaangażowany $\mathrm{w}$ okresach przesilenia społeczno-politycznego w Polsce praktycznie we wszystkie inicjatywy zwiazane $z$ próbami odrodzenia harcerstwa (w tym będących pokłosiem Października '56), z pewnościa orientował się $\mathrm{w}$ tych kwestiach doskonale. Ale nie wybrany do władz krajowej organizacji na tzw. Zjeździe Łódzkim (w wyniku taktyki przyjętej przez jego oponentów ${ }^{49}$ ), nie był chyba ani ich inicjatorem, ani zaufanym pośrednikiem także po grudniu 1956 roku m.in. pochłonięty praca nad wspomnieniami $z$ okresu okupacji. Inna sprawa, że „cudowne” odnalezienie w tym czasie materiałów historycznych na temat „Szarych Szeregów", skonfiskowanych mu jeszcze w 1948 roku, mogło być obliczone na jego dalszą neutralizację ${ }^{50}$. Bo, jak sam wspominał,

49 „Pewnego razu w trakcie obrad - rzecz działa się noca - Adam [Strzembosz - przyp. A.F.B.] zszedł do sutereny budynku, gdzie znajdowała się kuchnia, i stał się mimowolnym świadkiem zebrania partyjnego. Druhna Zofia Zakrzewska, późniejsza naczelniczka ZHP, namawiała towarzyszy, by w imię jedności harcerstwa dokooptować do władz kogoś z "prawdziwych". Opowiadała się za Kamińskim. - Broniewski jest młody, energiczny, dobrze mówi, a Kamiński to starzec zagrożony gruźlica i pewnie długo nie pociagnie - argumentowała. - To ja proponuję, żeby Kamińskiego zrobić przewodniczącym Rady Naczelnej ZHP. Adam, który przyszedł napić się wody, nie wytrzymał i wyskoczył z repliką. Przypomniano mu jednak, że nie jest członkiem organizacji partyjnej i nakazano opuścić pomieszczenie”. Cyt. za: W. Borek, A. Urbański, Strzembosz - portret rodzinny..., s. 150.

50 „Wracając do okresu stalinizmu: nawet ten smutny czas nie był w stanie zdeptać do końca autentycznego nurtu ruchu. Jakaś iskra zawsze się tliła. Tym łatwiej nadeszła 
hm. Zygmunta Szadkowskiego poznał osobiście dopiero w 1988 roku na światowym zlocie w Rising Sun (USA), zorganizowanym przez ZHPpgK, w którym po raz pierwszy uczestniczyli przedstawiciele harcerskich środowisk „niepokornych” i niezależnych z kraju.

Szybko pojałłem, jaką rolę odgrywał on w emigracyjnym świecie. [...] Gdy później przybył do kraju w ważnej misji przekazania władzy Rządu na Uchodźstwie w ręce powstającego właśnie wolnego Rządu w Kraju z Wałęsa i Mazowieckim na czele, nawiązaliśmy niezwłocznie ścisły kontakt. Uderzająco podobna była sytuacja ogólnych spraw państwowych oraz spraw idacego do wolności różnymi ścieżkami harcerstwa. Podobnymi metodami radził się kierować w obu sprawach Szadkowski. Istota tych metod było wychodzenie $z$ niespornych pozycji początkowych, z czasów, kiedy - jako wolni - sami stanowiliśmy. Druga metoda to zdecydowane podkreślanie siły, jaka przynosi jedność, i to zarówno z punktu widzenia wewnętrznego - siły kraju, jak i zewnętrznego - opinii świata.

Tak wspominał „Orsza”, ujawniając tym samym rolę, jaką spełniły te nieliczne kontakty $z$ emigracja $\mathrm{w}$ działaniach, które sam inicjował w krajowym harcerstwie dużo później, bo dopiero od końca 1989 $\mathrm{roku}^{51}$.

w 1956 r., wraz z Październikiem zmiana jak druga eksplozja. Łatwiejsza od obecnej [chodziło o rok 1981 - przyp. A.F.B.], bo przerwa czasowa była krótsza. Instruktorzy starej szkoły byli jeszcze w sile wieku (ja miałem 41 lat, moi wychowankowie okresu wojennego - trzydziestkę). Wszystko jeszcze odbywało się w obrębie tego samego pokolenia. Od 1958 roku nastapiło stopniowe, planowe wygaszanie odrodzenia ZHP. [...] Lecz tym razem owo wygaszanie nie doszło do końca. Pamiętam, przez cały czas przychodzili do mnie po cichu, w mundurkach, uprzedzałem, że może im to zaszkodzić; odpowiadali, że ich to nie martwi. [...] Pamiętam, odnalazły się nagle materiały, które mi w roku 1948 skonfiskowano. Sensacyjna paczka podrzucona w Bibliotece UW... Bardzo mi się przydała, bo ci młodzi byli spragnieni wiedzy i samodzielnie potrafili dotrzeć do takich źródeł, że mnie zaginali”. Cyt. za: S. Broniewski, Młodość przeżywa się raz! „Orszy” gawędy o wychowaniu, oprac. J. Błoniarz, Niezależne Wydawnictwo Harcerskie, Warszawa 2013, s. 141. Por. A.F. Baran, Stanisław Broniewski „Orsza” wobec wydarzen harcerskich w Polsce z lat 1980-1983, w: Od zniewolenia do wolności. Studia historyczne, red. A.F. Baran, Instytut Studiów Politycznych PAN, Collegium Civitas, Polskie Radio Białystok, Warszawa - Białystok 2009, s. 370-371; idem, Niebanalny życiorys - Stanisław Broniewski (1915-2000), w: S. Broniewski, Młodość przeżywa się raz!..., s. 280-281.

${ }^{51} \mathrm{~S}$. Broniewski „Orsza”, To nie takie proste. Moje życie, oprac. M. Szczęśniak, Wydawnictwo Wing, Warszawa 2001, s. 224. 
